\title{
Teasing and weight-control behaviors in adolescent girls
}

\author{
Provocações e comportamentos para controle de peso em adolescentes do sexo feminino \\ Provocaciones y comportamientos para control de peso en adolescentes del sexo femenino
}

Ana Carolina B. Leme' ${ }^{1}$ Sonia Tucunduva Philippi

\section{ABSTRACT}

Objective: To analyze the association between weight teasing, body satisfaction and weight control behaviors.

Methods: Cross-sectional study based on adaptation and validity research of a North American questionnaire for adolescent girls about physical activity, nutrition, body image, perceptions, and behaviors. The variables used to conduct the study were weight control behaviors, body satisfaction and presence of teasing by family members. Descriptive analyses were carried out by chi-square test, being significant $p \leq 0.05$.

Results: A total of 159 adolescent girls, with $16.2 \pm 1.3$ years old were enrolled in this study. Of the total, $60.1 \%$ reported that family members did not tease them. The teasing was associated with weight dissatisfaction $(p<0.001)$, body shape $(p=0.006)$, belly ( $p=0.001)$, waist $(p=0.001)$, face $(p=0.009)$, arms $(p=0.014)$ and shoulders $(p=0.001)$. As a consequence, there was association with unhealthy weight control behaviors $(p<0.001)$, vomiting $(p=0,011)$, $\operatorname{diet}(p=0.002)$ and use of laxatives $(p=0.035)$.

Conclusions: The teasing about body image by family members was associated with risk for unhealthy weight control behaviors in female adolescents.

Key-words: adolescent; feeding behavior; body image; obesity.

\section{RESUMO}

Objetivo: Analisar a associação entre as provocações relativas ao peso, a satisfação corporal e os comportamentos para controle de peso.

Métodos: Estudo transversal baseado em pesquisa de adaptação e validação de um questionário norte-americano para adolescentes do sexo feminino sobre percepções, comportamentos, atividade física, alimentação e imagem corporal. As variáveis utilizadas para a realização do estudo foram os comportamentos para controle de peso corporal, o grau de satisfação corporal e a presença de provocações relativas ao peso por parte de membros da família. Realizaram-se análises descritivas pelo teste do qui-quadrado, considerando-se significante $p \leq 0,05$.

Resultados: Participaram do estudo 159 adolescentes do sexo feminino, com idade de 16,2 $\pm 1,3$ anos. Do total, $60,1 \%$ relataram não ter sofrido provocações relativas ao peso por membros da família. As provocações associavam-se à insatisfação com peso $(p<0,001)$, forma do corpo $(p=0,006)$, abdome $(p=0,001)$, cintura $(p=0,001)$, rosto $(p=0,009)$, braços $(p=0,014)$ e ombros $(p=0,001)$. Consequentemente, houve associação com comportamentos não saudáveis para controlar o peso $(p<0,001)$, provocar vômito $(p=0,011)$, realizar dieta $(p=0,002)$ e tomar laxantes $(p=0,035)$.

Conclusões: As provocações relativas à imagem corporal por membros da família relacionam-se ao risco para compor-
Instituição: Faculdade de Saúde Pública da Universidade de São Paulo (USP), São Paulo, SP, Brasil

${ }^{1}$ Faculdade de Saúde Pública da USP, São Paulo, SP, Brasil

\author{
Endereço para correspondência: \\ Ana Carolina B. Leme \\ Avenida Dr. Arnaldo, 715 - Cerqueira César \\ CEP 01246-904 - São Paulo/SP \\ E-mail: acarol.leme@gmail.com \\ Fonte financiadora: Coordenação de Aperfeiçoamento de Pessoal de Nível \\ Superior (Capes) - cota institucional \\ Conflito de interesse: nada a declarar \\ Recebido em: 27/2/2013 \\ Aprovado em: 10/5/2013
}


tamentos não saudáveis para controle de peso em adolescentes do sexo feminino.

Palavras-chave: adolescente; comportamento alimentar; imagem corporal; obesidade.

\section{RESUMEN}

Objetivo: Analizar la asociación entre las provocaciones relativas al peso, la satisfacción corporal y los comportamientos para control de peso.

Métodos: Estudio transversal basado en investigación de adaptación y validación de un cuestionario estadounidense para adolescentes del sexo femenino sobre percepciones, comportamientos, actividad física, alimentación e imagen corporal. Las variables utilizadas para la realización del estudio fueron los comportamientos para control de peso corporal, el grado de satisfacción corporal y la presencia de provocaciones relativas al peso por parte de miembros familiares. Se realizaron análisis descriptivos por la prueba del chi-cuadrado, considerándose diferencias estadísticamente significantes para $p \leq 0,05$.

Resultados: Participaron del estudio 159 adolescentes del sexo femenino, con promedio de edad de 16,2 y desviación estándar de 1,27 años. Del total, 60,1\% relataron no haber sufrido provocaciones relativas al peso por miembros familiares. Las provocaciones se asociaban a la insatisfacción con el peso $(p<0,001)$, forma del cuerpo $(p=0,006)$, abdomen $(p=0,001)$, cintura $(p=0,001)$, cara $(p=0,009)$, brazos $(p=0,014)$ y hombros $(p=0,001)$. Por consiguiente, hubo asociación con comportamientos no sanos para controlar el peso $(p<0,001)$, provocar vómito $(p=0,011)$, realizar dieta $(p=0,002)$ y tomar laxante $(p=0,035)$.

Conclusiones: Tales provocaciones se relacionan al riesgo para comportamientos no sanos para control de peso.

Palabras clave: adolescente; comportamiento alimentar; imagen corporal; obesidad.

\section{Introduction}

Teasing among adolescents, also known as emotional bullying, is a worrying issue that may be related to health risks. A representative American study with children and adolescents from two to 17 years old estimated that one out of four children reported being teased ${ }^{(1)}$. Teasing may involve several negative comments, such as jokes and nicknames, which are frequently accompanied by acts of social aggression such as exclusion, isolation and humiliation ${ }^{(2)}$.

Weight teasing is common among adolescents, especially among girls and overweight individuals, and nearly $72 \%$ of female adolescents and college students reported that they were teased because of their appearance in childhood and adolescence ${ }^{(2)}$. Teasing has been found to be associated with restrictive eating, bulimic behaviors, lack of self-esteem, thin-ideal internalization, and depression. Therefore, there is a causal relationship between body dissatisfaction and insults, suggesting that teasing during adolescence may be a risk factor for self-image dissatisfaction in adulthood ${ }^{(2)}$.

The sources of weight teasing reported in studies on the subject include parents, siblings, peers, and other adults (e.g., teachers and sports coaches $)^{(3,4)}$. Although peers are considered the main bullies, parents and/or other family members also contribute to teasing ${ }^{(5-7)}$. Family environment has been identified as an important influence for weight-related outcomes in children and adolescents ${ }^{(8)}$. Weight-related comments by family members, as well as parents' model and the encouragement to engage in a weight loss diet, may have adverse effects on the youth, being often more dangerous than indirect factors, such as seeing their parents dieting ${ }^{(9,10)}$.

Bardone-Cone et $a^{(11)}$ and Lunde et $a^{(12)}$ suggest that teasing may have different impacts in terms of gender, with higher influence on body dissatisfaction in boys than in girls. Although body image and restrictive eating behaviors vary culturally, weight teasing is associated with inappropriate eating behaviors and body dissatisfaction in different contexts.

In this sense, it is necessary to carry out studies addressing weight teasing experienced by adolescents, because it is a risk factor for inappropriate eating behaviors that lead both to obesity and eating disorders. Thus, based on Brazilian observational studies, it is possible to draw a diagnosis and implement appropriate intervention strategies. This study analyzed the association between weight teasing, body image, and weight control behaviors in adolescent girls.

\section{Method}

The present study originated from adaptation and validity research of an American questionnaire about "Perceptions, attitudes and behaviors related to physical activity, eating and body image", conducted in November 2012, in São Paulo, Brazil. It was a cross-sectional study that used a nonprobabilistic sampling method and had a target population 
of adolescent girls from 13 to 19 years old enrolled in public and private elementary and high schools in the state of São Paulo. The coordinators of the participating schools gave permission for the study to be carried out during Physical Education classes. Therefore, the girls present in the classes and who had provided written consent signed by parents/ guardians were eligible for the study, with no losses or withdrawals. We included adolescent girls from 13 to 19 years enrolled from the eighth grade of elementary school to the third grade of high school and who participated in the stage of adaptation and validation of the questionnaire.

The results obtained in a longitudinal study called Project EAT (Eating Among Teens), by the University of Minnesota, United States, enabled to develop a questionnaire to be used in the implementation of an intervention program for the prevention of obesity and eating disorders in adolescent girls called New Moves, organized by the same institution. Such questionnaire was submitted and authorized by the researcher to the team of this study.

The cross-cultural adaptation and translation protocols followed the procedures proposed by Reichenheim and Moraes $^{(13)}$ and involved four stages: initial translation, backtranslation, review by an expert committee, and cultural adaptation. After being adapted, the questionnaire was validated for use with the girls. School coordinators, teachers and students were approached and informed about the nature of the study, objectives, and the principle of secrecy. Girls participated in data collection after providing written informed consent signed by their parents/guardians.

The final version of the questionnaire comprised 29 closed questions, with yes/no, agree/disagree, and Likert scale answers. As seen in the title of the questionnaire, study variables included perceptions, attitudes and behaviors regarding physical activities, nutrition and body image. However, for the present analysis, we used variables related to body image (body satisfaction and weight teasing) and to eating behaviors (healthy and unhealthy weight control behaviors).

Participants were asked to report (by yes/no answers) 15 strategies used in the last year to reduce or maintain weight. These items were compiled into two scales, using Cronbach's $\alpha$ coefficient: healthy and unhealthy weight control behaviors. Healthy behaviors included the following items: reducing the amount of food they eat, practicing physical activity, increasing fruit and vegetable intake, reducing the intake of soft or sugary drinks, reducing the intake of sweets, fried and packaged snacks, and other "treats", paying attention to the size of the portions. This scale had a reliability coefficient of $\alpha=0.74$. Unhealthy behaviors included: fasting, skipping meals, taking laxatives, diuretics and others medications, vomiting, smoking, using food replacements (shakes and cereal bars), and undergoing a weight control diet. This scale had an acceptable reliability coefficient of $\alpha=0.60$. In addition to these behaviors, girls should inform about the presence of binge-eating (using yes/no answers) through the question: "in the last month, did you eat a great amount of food by yourself, without being able to stop, and felt embarrassed about it"?

Body satisfaction was assessed by three types of answer (dissatisfied, indifferent, or satisfied) for height, weight, body shape, hip, thigh, abdomen, waist, face, arms and shoulders $(\alpha=0.87)$.

Weight teasing was assessed by the question: "in the last year, did someone in your family make jokes about your weight and/or physical appearance?"

Data were stored on Excel software (version for Mac), typed twice in order to prevent possible typing errors, and analyzed on STATA software (version 9.1) for Windows. Descriptive analysis was carried out by mean, standard deviation, and frequency. Possible associations between teasing, body satisfaction, and weight control behaviors were investigated by chi-square test, with statistic significant differences set at $p \leq 0.05$.

This study was approved by the Research Ethics Committee of the Public Health School of Universidade de São Paulo (USP), according to the resolution 196, of October 10, 1996. All girls provided written informed consent signed by their parents or guardians.

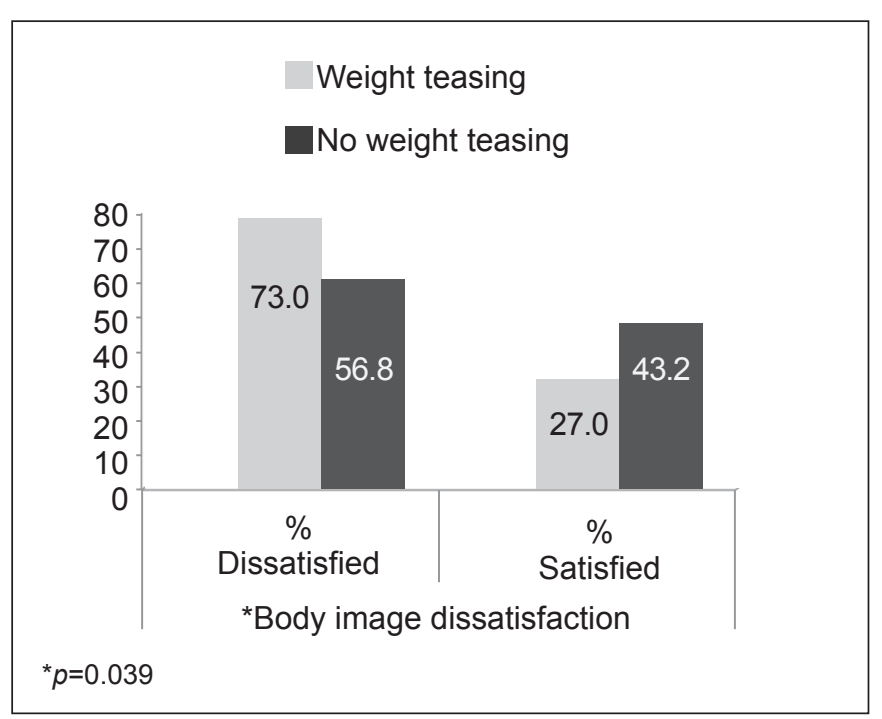

Figure 1 - Weight teasing according to body satisfaction among adolescent girls. São Paulo, Brazil, 2012 
Table 1 - Weight teasing and body satisfaction among adolescent girls. São Paulo, Brazil. 2012

\begin{tabular}{|c|c|c|c|c|c|c|c|}
\hline \multirow{2}{*}{ Body areas } & \multicolumn{2}{|c|}{ Dissatisfied } & \multicolumn{2}{|c|}{ Indifferent } & \multicolumn{2}{|c|}{ Satisfied } & \multirow{2}{*}{$p$-value } \\
\hline & $\mathbf{n}$ & $\%$ & $\mathbf{n}$ & $\%$ & $n$ & $\%$ & \\
\hline Height & 11 & 17.46 & 23 & 36.51 & 29 & 46.03 & 0.304 \\
\hline Weight & 33 & 52.38 & 18 & 28.57 & 12 & 19.05 & $<0.001$ \\
\hline Body shape & 19 & 30.65 & 21 & 33.87 & 22 & 35.48 & 0.006 \\
\hline Hip & 21 & 33.33 & 19 & 30.16 & 23 & 36.51 & 0.077 \\
\hline Thigh & 19 & 30.16 & 20 & 31.75 & 24 & 38.10 & 0.249 \\
\hline Waist & 26 & 41.27 & 13 & 20.63 & 24 & 38.10 & 0.001 \\
\hline Face & 12 & 19.05 & 23 & 36.51 & 28 & 44.44 & 0.009 \\
\hline Arms & 20 & 32.26 & 21 & 33.87 & 21 & 33.87 & 0.014 \\
\hline Shoulders & 12 & 19.05 & 29 & 46.03 & 22 & 34.92 & 0.001 \\
\hline
\end{tabular}

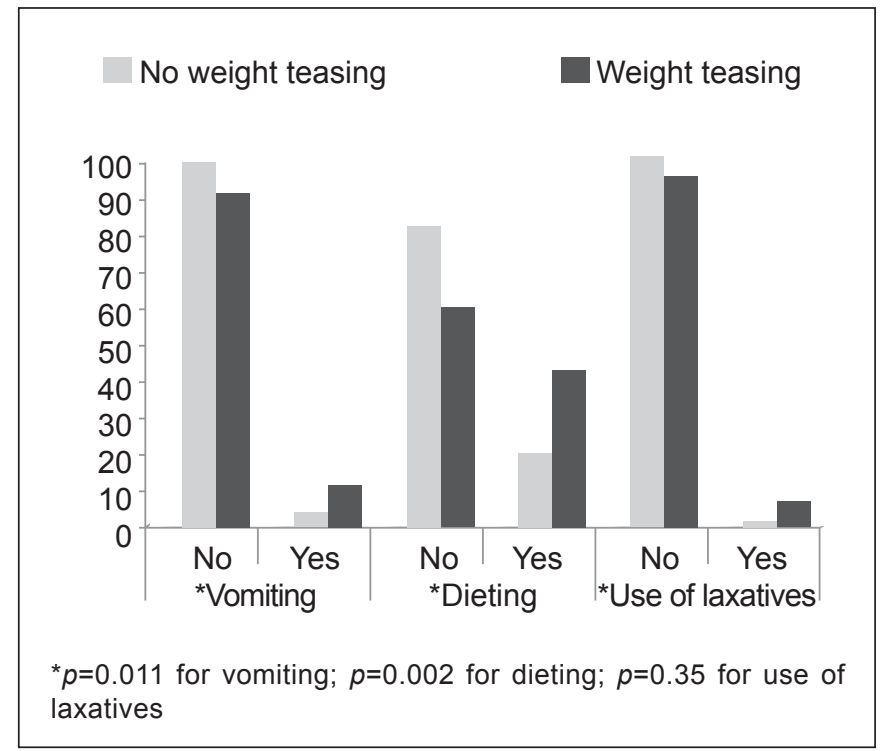

Figure 2 - Presence of weight teasing and inappropriate weight control behaviors among adolescent girls. São Paulo, Brazil, 2012

\section{Results}

A total of 159 adolescent girls, with a mean age of 16.2 years and a standard deviation of 1.27 years participated in this study; of these girls, $60.1 \%$ reported that family members did not tease them about their weight/appearance throughout the year of data collection. Body satisfaction was associated with weight teasing by family members $(p=0.04)$. A total of 101 girls (63.52\%) were dissatisfied with at least one part of their body (Figure 1). The presence of weight teasing also showed statistically significant differences for some areas of the body (Table 1).
Also because of teasing, differences were observed for some inappropriate weight control behaviors (Figure 2). Compulsive eating behaviors were also associated with teasing about girl's weight $(p=0.05)$.

\section{Discussion}

There are few Brazilian studies on the subject. However, some national investigations assessed body satisfaction and/or inappropriate weight control behaviors and associated them with eating disorders ${ }^{(14-16)}$. At the international level, relevant results were found, indicating an association of teasing by family members and/or friends with body image dissatisfaction and weight control behaviors, especially those related to restrictive diets, skipping of meals, and body weight dissatisfaction ${ }^{(6,7,17,18)}$.

National studies ${ }^{(14-16)}$ that assessed body image satisfaction often use body silhouette scales. A set of silhouettes is presented to adolescents, who usually answer to two questions: "which silhouette better represent your current body appearance (real)?" and "which body silhouette would you like to have (ideal)?" When the variation between real and ideal silhouettes is equal to zero, adolescents are classified as satisfied; when it is different from zero, they are classified as dissatisfied. However, some national ${ }^{(19-21)}$ and international studies adopted other evaluation methods instead of using body figures. The use of questions to assess satisfaction with weight, height and different areas of the body (e.g., abdomen and thighs) ${ }^{(19-21)}$, by means of categorical answers ranging from "very dissatisfied" to "very satisfied", is a good choice, since answers obtained in questionnaires reflect a greater concern with body image 
and greater self-deprecation due to physical appearance, especially in cases of excess body weight ${ }^{(19)}$.

Therefore, the results from this study are in accordance with the methodological techniques used in previous studies and indicate that weight teasing, body dissatisfaction, and unhealthy weight control behaviors are prevalent in adolescent girls. Rojo-Moreno et al ${ }^{(22)}$ conducted a Spanish multicenter study with 57,997 adolescents from 13 to 16 years old and found differences between body bullying and gender. This was also observed by Slater and Tiggermann ${ }^{(18)}$ in a study with 714 adolescents from 12 to 16 years old in Adelaide, Australia. Although body bullying showed more severe effects in boys as for BMI and body image dissatisfaction, girls are more exposed to criticism about physical appearance in multiple contexts, including the media $^{(18,22,23)}$. Girls usually suffer more due to body bullying in comparison to boys, and feel more bothered by teasing, which contributes to body dissatisfaction and inappropriate weight control behaviors ${ }^{(2,23,24)}$.

The susceptibility of girls to these behaviors may be also attributed to comments made between themselves about weight and appearance, because of the persuasive nature of opinions about body fat and the important role of women in society. Additionally, the female "ideal of thinness" was strongly adopted in Western culture and influences opinions about appearance or body weight ${ }^{(5)}$.

Overweight individuals are more prone to receive offensive comments about their appearance. The likelihood of being the target of comments by family members is higher for obese youngsters compared to normal weight youngsters $^{(3,5)}$. Like the research by Eisenberg et $a l^{(5)}$, this study used a questionnaire to investigate topics related to weight and the presence of teasing by family members. Although the questionnaire had not specified which family member was the aggressor, the result is consistent with the family systems theory, which states that the relationships between family members may lead to sustainable patterns of interaction. Young adults who were teased during adolescence will probably continue to be teased, because behavioral patterns are established over time ${ }^{(5)}$.

Teasing by family members may be very important, showing a consistent correlation with unwanted weight effects. Girls who reported to suffer from teasing or inappropriate jokes about their weight by family members show greater body dissatisfaction and greater susceptibility to unhealthy eating behaviors, such as binge-eating, in comparison to girls who were not insulted. The associations found here are consistent with previous studies ${ }^{(2,21,25-27)}$. Girls often do not demonstrate to be bothered by weight teasing, although it may lead to inappropriate behaviors, such as dieting, skipping of meals, and fasting ${ }^{(21)}$. Girls who are frequently teased are ten times more likely to develop binge-eating than those who are not ${ }^{(2,21)}$.

Therefore, results suggest that girls who suffered from body bullying were more predisposed to inappropriate weight control behaviors, such as purging practices and especially restrictive diets, than girls who were not bullied, and were less predisposed to engage in healthy behaviors, such as increasing fruit and vegetable intake, reducing the intake of soft and sugary drinks, and practicing different types of physical activity. Girls insulted by only one source (e.g., parents and peers) showed a higher trend towards dieting. When two sources are involved, there is the risk for more restrictive practices ${ }^{(16)}$. These results were similar to those from previous studies, which reported an association between teasing and inappropriate behaviors ${ }^{(3,16)}$. In other words, results suggest that being teased about their weight does not seem to motivate overweight adolescent girls to engage in healthy weight control behaviors.

Some limitations of the study should be considered. In face of the results from this research, which had a crosssectional design and used a non-probabilistic (convenience) sample, the data obtained cannot be extrapolated to the entire adolescent population. The variable teasing was measured by only one item and thus does not have strong psychometric properties for the question. The use of improved and more extensive measures may be useful in this area of study, such as the inclusion of questions about the source of teasing (parents, relatives and peers) and the frequency at which it occurs. It is possible to distinguish the intensity of teasing from other general comments, in the sense of differentiating its severity, the type of psychological morbidity, and the inappropriate eating behavior. Despite these limitations, this study is one of the first at the national level to observe several weight control behaviors and body satisfaction, relating them to the presence of weight teasing in adolescent girls.

It is possible to conclude that results show an association between weight teasing, body dissatisfaction, and unhealthy weight control behaviors. Additionally, this study observed that teasing was also related to the presence of binge-eating, which may lead to body weight gain. 


\section{References}

1. Finkelhor D, Ormrod R, Turner H, Hamby SL. The victimization of children and youth: a comprehensive, national survey. Child Maltreat 2005;10:5-25.

2. Menzel JE, Schaefer LM, Burke NL, Mayhew LL, Brannick MT, Thompson JK. Appearance-related teasing, body dissatisfaction, and disordered eating: a meta-analysis. Body Image 2010;7:261-70.

3. Neumark-Sztainer D, Falkner N, Story M, Perry C, Hannan PJ, Mulert S. Weight-teasing among adolescents: correlations with weight status and disordered eating behaviors. Int J Obes Relat Metab Disord 2002;26:123-31.

4. Haines J, Neumark-Sztainer D, Hannan PJ, Eisenberg ME. Longitudinal and secular trends in weight-related teasing during adolescence. Obesity (Silver Spring) 2008;16 (Suppl 2):S18-23.

5. Eisenberg ME, Berge JM, Fulkerson JA, Neumark-Sztainer D. Weight comments by family and significant others in young adulthood. Body Image 2011;8:12-9.

6. Puhl RM, Luedicke J. Weight-based victimization among adolescents in the school setting: emotional reactions and copying behaviors. J Youth Adolesc 2012;41:27-40.

7. Puhl RM, Peterson JL, Luedicke J. Weight-based victimization: bullying experiences of weight loss treatment-seeking youth. Pediatrics 2013;131:e1-9.

8. Golan M. Parents as agents of change in childhood obesity - from research to practice. Int J Pediatr Obes 2006;1:66-76.

9. Fulkerson JA, McGuire MT, Neumark-Sztainer D, Story M, French SA, Perry CL. Weight-related attitudes and behaviors of adolescent boys and girls who are encouraged to diet by their mothers. Int J Obes Relat Metab Disord 2002;26:1579-87.

10. Keery H, Eisenberg ME, Boutelle K, Neumark-Sztainer D, Story M. Relationships between maternal and adolescent weight-related behaviors and concerns: the role of perception. J Psychosom Res 2006;61:105-11.

11. Bardone-Cone AM, Cass KM, Ford JA. Examining body dissatisfaction in young men within a biopsychosocial framework. Body Image 2008;5:183-94.

12. Lunde C, Frisén A, Hwang P. Ten-year-old girls' and boys' composition and peer victimization experiences: prospective associations with body satisfaction. Body Image 2007;4:11-28.

13. Reichenheim ME, Moraes CL. Operationalizing the cross-cultural adaptation of epidemological measurement instruments. Rev Saude Publica 2007;41:665-73.

14. Fidelix YL, Silva DA, Pelegrini A, Silva AF, Petroski EL. Body image dissatisfaction among adolescents from a small town: association with gender, age, and area of residence. Rev Bras Cineantropom Desempenho Hum 2011;13:202-7
15. Pelegrini A, Silva DA, Silva AF, Petroski EL. Insatisfação corporal associada a indicadores antropométricos em adolescentes de um cidade com índice de desenvolvimento humano médio a baixo. Rev Bras Cienc Esporte 2011;33:687-98.

16. Petroski EL, Pelegrini A, Glaner MF. Reasons and prevalence of body image dissatisfaction in adolescents. Cienc Saude Coletiva 2012;17:1071-7.

17. Libbey HP, Story MT, Neumark-Sztainer DR, Boutelle KN. Teasing, disordered eating behaviors, and physicological morbidities among overweight adolescents. Obesity (Silver Spring) 2008;16 (Suppl 2):S24-9.

18. Slater A, Tiggermann M. Gender differences in adolescent sport participation, teasing, self-objectfication and body image concerns. J Adolesc 2011;34:455-63.

19. Martins CR, Pelegrini A, Matheus SC, Petroski EL. Body image dissatisfaction and its relationship with nutritional status, body fat, and anorexia and bulimia symptoms in adolescents. Rev Psiquiatr Rio Gd Sul 2010;32:19-23.

20. Santos EM, Tassitano RM, Nascimento WM, Petribú MM, Cabral PC. Body satisfaction and associated factors among high school students. Rev Paul Pediatr 2011;29:214-23.

21. Neumark-Sztainer D, Bauer KW, Friend S, Hannan PJ, Story M, Berge JM. Family weight-talk and dieting: how much do they matter for body dissatisfaction and disordered eating behaviors in adolescent girls? J Adolesc Health 2010;47:270-6.

22. Rojo-Moreno L, Rubio T, Plumed J, Barberá M, Serrano M, Gimeno N et al. Teasing and disordered eating behaviors in Spanish adolescents. Eat Disord 2013;21:53-69.

23. Goldfield GC, Moore C, Henderson K, Buchholz A, Obeid N, Flament M. The relation between weight-based teasing and physichological adjustment in adolescents. Paediatr Child Health 2010;15:283-8.

24. Losekam S, Goetzky B, Kraeling S, Rief W, Hilbert A. Physical activity in normal-weight and overweight youth: associations with weight teasing and self-efficacy. Obes Facts 2010;3:239-44.

25. McCabe MP, Ricciardelli LA. A prospective study of pressures from parents, peers, and the media on extreme weight change behaviors among adolescent boys and girls. Behav Res Ther 2005;43:653-68

26. Keery H, Boutelle K, van den Berg P, Thompson JK. The impact of appearancerelated teasing by family members. J Adolesc Health 2005;37:120-7.

27. Hanna AC, Bond MJ. Relationships between family conflict, perceived maternal verbal messages, and daughters' disturbed eating symptomatology. Appetite 2006;47:205-11. 